\title{
BIOLOGY OF CAVE CRICKETS, HADENOECUS SUBTERRANEUS, AND CAMEL CRICKETS, CEUTHOPHILUS STYGIUS (INSECTA: ORTHOPTERA): METABOLISM AND WATER ECONOMIES RELATED TO SIZE AND TEMPERATURE
}

\author{
Eugene H. Studier and Kathleen H. Lavoie \\ Department of Biology, University of Michigan-Flint, Flint, MI 48502-2186, USA
}

(Received 11 July 1989)

\begin{abstract}
Metabolic rate (MR) and water budget (WB) components of cave and camel crickets are directly related to size and temperature.

2. MR increases most rapidly with size for insects in general followed by cave crickets (females $>$ males), and lastly, camel crickets (no sex differences).

3. Metabolic thermal sensitivity of cave crickets (males $>$ females) is much greater than camel crickets.

4. WB components parallel MR relations.
\end{abstract}

\section{INTRODUCTION}

In karsted regions of Kentucky, cave crickets (Hadenoecus subterraneus) and camel crickets (Ceuthophilus stygius) represent the bulk of biomass present in many caves and through their wastes, eggs and carcasses represent the most dependable source of fixed energy for troglobites (Barr, 1967; Barr and Kuehne, 1971; Richards, 1971; Harris, 1973). With the exception of their taxonomic relations and geographic distributions (Hubbell, 1936; Hubbell and Norton, 1978), few aspects of the biology of these trogloxenes have been significantly investigated. The interrelations of $H$. subterraneus and their egg predator Neaphenops tellkampfi, have been studied extensively (Poulson, 1975; Norton et al., 1975; Kane and Poulson, 1976). Our general interest in the physiological ecology of cavernicolous organisms, coupled with the biological importance of these insects to cave ecosystems, has stimulated our continuing examination of these insects (Studier et al., 1986, 1987a, $1987 \mathrm{~b}, 1989$ ). This study reports metabolic rates and water budget components in these two species as functions of size and temperature.

\section{MATERIALS AND METHODS}

Metabolic rates (MR) and water budget (WB) components were calculated essentially as previously described (Studier et al., 1986, 1987a, b). The relations of these variables to size in $C$. stygius (65 crickets tested) were done on 25-30 July 1986, 19-24 October 1986, 22-24 February 1987 and 26-30 April 1987, with individuals collected from entrance areas of Great Onyx, Frozen Niagara, and Crystal Caves and tested in Crystal Cave or Marion Avenue of Mammoth Cave. Relations of MR and WB components to size in $H$. subterraneus (62 crickets) were studied on 22-24 February 1987 with crickets collected from the entrance of Frozen Niagara and Sophys Avenue of Mammoth Cave and tested in Marion Avenue of Mammoth Cave. Ambient temperature $\left(T_{\mathrm{a}}\right)$ for all size studies was normal cave $T_{\mathrm{a}}$ of $13.0 \pm 0.5^{\circ} \mathrm{C}$. The only variations from previously described methods were that small size crickets were caged in pint rather than quart jars and successive weights of crickets studied in Marion Avenue were taken with an electronic balance accurate to $0.1 \mathrm{mg}$ (Fisher Scientific, Model 2100).

The relations of $T_{\mathrm{a}}$ to $\mathrm{MR}$ and WB components in 48 C. stygius were studied from 8-11 July 1987 on individuals collected from the entrance to Great Onyx Cave and in $48 \mathrm{H}$. subterraneus were studied from 27-30 April 1987 on crickets collected from the entrance area of Crystal Cave and Sophys Avenue of Mammoth Cave. These studies were done in Marion Avenue of Mammoth Cave using the previously mentioned electronic balance. Below cave $T_{\mathrm{a}}$ of $9.5^{\circ} \mathrm{C}$ was achieved in a Styrofoam cooler containing ice and $T_{\mathrm{a}} \mathrm{s}$ above cave temperature werc obtained with incubators containing trays of water to insure water saturated air in the incubators. Cave crickets were tested at $T_{\mathrm{a}} \mathrm{s}$ above cave $T_{\mathrm{a}}$ at $16.0,18.5,22.0$ and $25^{\circ} \mathrm{C}$. Camel crickets were tested at $T_{\mathrm{a}} \mathrm{s}$ above cave $T_{\mathrm{a}}$ of $19.5,23.5,27.5$ and $31.0^{\circ} \mathrm{C}$. Weight loss was followed for $40-48 \mathrm{hr}\left(14-18 \mathrm{hr}\right.$ at the highest two $\left.T_{\mathrm{d}} \mathrm{s}\right)$ for both species.

Hind femur lengths (HFL) and sex were determined and recorded for all studied crickets. Crop empty live weight (CELW), termed crop-free live weight (CFLW) in our first study, for all crickets was determined by dissection or by use of a HFL to CELW relationship as previously described (Studier et al., 1986). Percent water of crop contents and carcasses and dry caloric densities of crop contents were also calculated as previously described.

\section{RESULTS}

Exponential relations of MR to CELW for the crickets studied as well as insects in general are shown in Fig. 1. Table 1 gives the relations of MR and WB components to CELW for both species. Linear slopes of mass to MR relations of male and female $C$. stygius do not differ, while slopes for $H$. subterraneus differ significantly $(t=2.846 ; 56 \mathrm{df}, P<0.01$ ).

Size-specific metabolic rates of studied crickets in relation to $T_{\mathrm{a}}$ are shown in Fig. 2 and enumerated in Table 2. Weight specific MR and WB components in relation to $T_{\mathrm{a}}$ for both species are given in Table 3 . Percent water in crops and carcasses as well as caloric 


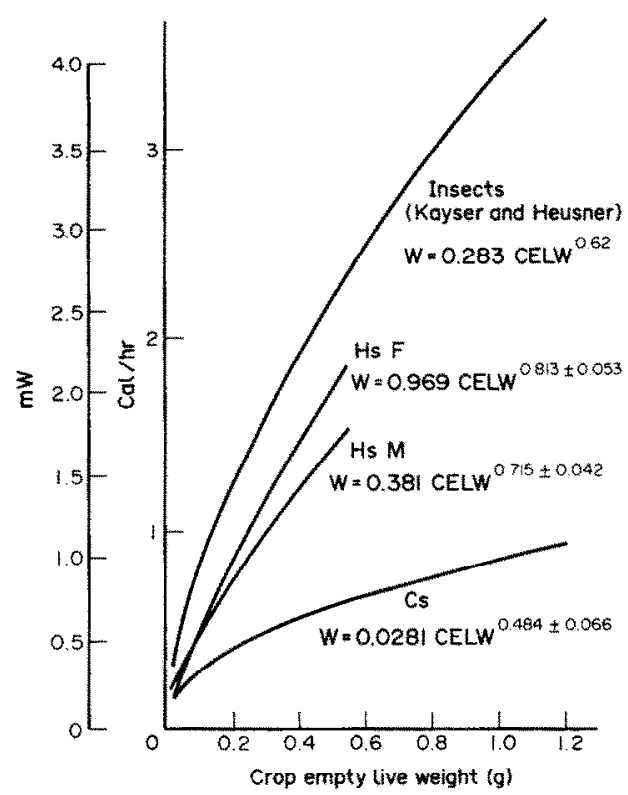

Fig. 1. Relation of metabolic rate (in Watts. W, or cal/hr) to mass (crop-empty live weight, CELW in $\mathrm{kg}$ ) in insects in general (Kayser and Heusner, 1964), female $H$. subterraneus $\left(F=230.47 ; \mathrm{df}=1\right.$ and $\left.32 ; P<0.0001 ; r^{2}=0.878\right)$, male $H$. subterraneus $(F=287.35 ; \mathrm{df}=1$ and $26 ; P<0.0001$; $\left.r^{2}=0.917\right)$ and combined sexes in $C$. stygius $(F=54.105$ $\mathrm{df}=1$ and $\left.63 ; P<0.0001 ; r^{2}=0.462\right)$.

density of crop contents are given in previous papers (Studier et al., 1986, 1987a, b).

\section{DISCUSSION}

The expected increase in absolute MR (power or energy/time) with increasing mass in animals



Fig. 2. Relation of metabolic size adjusted metabolic rate (cal $/ \mathrm{g} / \mathrm{hr}$ ) of cave and camel crickets as functions of ambient temperature $\left(T_{\mathrm{a}}\right.$ in $\left.{ }^{\circ} \mathrm{C}\right)$. See legend of Table 2 for units of metabolic rate

(whenever a broad enough range in mass is available) is seen in this study. In $H$. subterraneus, MR increases more rapidly with mass in females than in males; however, there are no gender related differences in C. stygius. Metabolic rates of cave crickets are greater than in camel crickets of similar size. Adult $H$. subterraneus in this study exhibited MR which were higher than in our previous study (Studier $e t$ al., 1986), while the MR of $C$. stygius in this study are very much lower than in our previous study (Studier et al., 1987a). These differences may reflect seasonal differences in MR which will be discussed in a later paper. MR of $H$. subterraneus, reported here in terms

Table 1. ANOVA results and regression coefficients for metabolic rate (cal/hr) and weight specific water budget components ( $\mathrm{mg} / \mathrm{g} / \mathrm{hr}$ ) as functions of size $(\mathrm{g})$. Regression equations are of the form $y=b x+c$ or $y=a x^{2}+b x+c$, where $x$ is mass in grams. Dependent variables (DV) include metabolic rate (MR),

\begin{tabular}{|c|c|c|c|c|c|c|c|}
\hline DV & $a$ & $\mathrm{~b}$ & $\mathrm{c}$ & df & $F$ & $r^{2}$ & $P$ \\
\hline \multicolumn{8}{|c|}{ H. subterraneus (males) } \\
\hline MR & & $\begin{array}{c}3.058 \\
(0.252)\end{array}$ & $\begin{array}{c}0.0886 \\
(0.0679)\end{array}$ & 1,26 & 147.06 & 0.8497 & $<0.0001$ \\
\hline CWG & $\begin{array}{c}49.84 \\
(14.65)\end{array}$ & $\begin{array}{r}-30.75 \\
(6.75)\end{array}$ & $\begin{array}{c}6.077 \\
(0.467)\end{array}$ & 2,25 & 27.545 & 0.6878 & $<0.0001$ \\
\hline MWG & $\begin{array}{c}6.641 \\
(2.558)\end{array}$ & $\begin{array}{r}-3.978 \\
(1.179)\end{array}$ & $\begin{array}{c}0.9404 \\
(0.0816)\end{array}$ & 2,25 & 13.419 & 0.5177 & $=0.0001$ \\
\hline TWG & $\begin{array}{c}56.49 \\
(17.00)\end{array}$ & $\begin{array}{r}-34.73 \\
(7.84)\end{array}$ & $\begin{array}{r}7.017 \\
(0.542)\end{array}$ & 2,25 & 25.747 & 0.6732 & $<0.0001$ \\
\hline \multicolumn{8}{|c|}{ H. subterraneus (females) } \\
\hline MR & & $\begin{array}{l}4.546 \\
0.458\end{array}$ & $\begin{array}{c}-0.0363 \\
(0.1183)\end{array}$ & 1,32 & 98.51 & 0.7548 & $<0.0001$ \\
\hline CWG & $\begin{array}{c}39.60 \\
(11.05)\end{array}$ & $\begin{array}{r}-24.96 \\
(5.99)\end{array}$ & $\begin{array}{c}5.562 \\
(0.529)\end{array}$ & 2,31 & 10.723 & 0.4089 & $=0.0003$ \\
\hline MWG & $\begin{array}{c}5.823 \\
(1.844)\end{array}$ & $\begin{array}{c}-3.423 \\
(1.000)\end{array}$ & $\begin{array}{c}0.9004 \\
(0.0883)\end{array}$ & 2,31 & 6.166 & 0.2846 & $=0.0056$ \\
\hline TWG & $\begin{array}{c}45.52 \\
(12.82)\end{array}$ & $\begin{array}{r}-28.38 \\
(6.95)\end{array}$ & $\begin{array}{c}6.465 \\
(0.613)\end{array}$ & 2,31 & 10.097 & 0.3945 & $=0.0004$ \\
\hline \multicolumn{8}{|c|}{ C. stygius (both sexes) } \\
\hline MR & & $\begin{array}{r}0.6590 \\
(0.993)\end{array}$ & $\begin{array}{c}3.263 \\
(0.076)\end{array}$ & 1,63 & 43.996 & 0.4112 & $<0.0001$ \\
\hline cWG & $\begin{array}{c}1.669 \\
(0.563)\end{array}$ & $\begin{array}{r}-3.186 \\
(0.755)\end{array}$ & $\begin{array}{c}2.177 \\
(0.174)\end{array}$ & 2,62 & 27.906 & 0,4737 & $<0.0001$ \\
\hline$M W G$ & $\begin{array}{c}0.5665 \\
(0.1405)\end{array}$ & $\begin{array}{r}-1.021 \\
(0.188)\end{array}$ & $\begin{array}{c}0.5484 \\
(0.0435)\end{array}$ & 2,62 & 37.500 & 0.5474 & $<0.0001$ \\
\hline TWG & $\begin{array}{c}2.236 \\
(0.696)\end{array}$ & $\begin{array}{c}4.209 \\
(0.932)\end{array}$ & $\begin{array}{r}2.726 \\
(0.215) \\
\end{array}$ & 2,62 & 30.379 & 0.4949 & $<0,0001$ \\
\hline
\end{tabular}


Table 2. ANOVA results and regression coefficients for metabolic size specific metabolic rates (MR) as functions of temperature. Regression equations are all of the form $\mathrm{MR}=a x^{2}+b x+c$, where $x$ is $T_{\mathrm{a}} \mathrm{in} \mathrm{C}$. Units for $\mathrm{MR}$ are cal $/ \mathrm{g}^{0.513} / \mathrm{hr}$ for female $H$. subterraneus, cal $/ \mathrm{g}^{0.715} / \mathrm{hr}$ for male $H$, stbterraneus and $\mathrm{cal} / \mathrm{g}^{0.484} / \mathrm{hr}$ for $\mathrm{C}$. stygius. Standard errors of the means are given in parentheses.

\begin{tabular}{lccccc}
\hline \multicolumn{6}{c}{ In all cases, $p<0.0001$} \\
\hline a & $\mathrm{b}$ & $\mathrm{c}$ & $\mathrm{df}$ & $F$ & $r^{2}$ \\
\hline H. subterraneus & (females) & & & & \\
0.05692 & -1.213 & 9.673 & 2,21 & 31.477 & 0.7477 \\
$(0.02126)$ & $(0.7444)$ & $(6.111)$ & & & \\
H. subterraneus (males) & -2.210 & 16.41 & 2,21 & 117.53 & 0.9180 \\
0.08794 & $(0.448)$ & $(3.68)$ & & & \\
$(0.01279)$ & -0.3243 & 2.343 & 2,44 & 50.609 & 0.6970 \\
C. stygins (both sexes) & $(0.1590)$ & $(1.436)$ & & & \\
0.01386 & $0.00394)$ & & & & \\
\hline
\end{tabular}

of CELW, are doubless maximal when compared to insects in general where $\mathrm{MR}$ is normally expressed per gram live weight instead of CELW. Since crop content wet weight (CWW) may easily equal CELW, expression of MR per gram live weight for cave crickets would reduce reported $M R$ by half. In $C$. stygius, $C W W$ represents a much smaller fraction of live weight, and is often zero and, therefore, would have little effect on reported MR. The frequent occurrence of empty crops in the
C. stygius studied would, in fact, yield a marked understatement of MR if those crickets were metabolizing stored body fat instead of crop contents. Caloric density of fat, about $9.5 \mathrm{kcal} / \mathrm{g}$, greatly exceeds the $\mathrm{kcal} / \mathrm{g}$ dry weight of crop contents of camel crickets; thus, MR of $C$. stygius may be up to twice the reported level. Since cave crickets routinely contain significant crop contents, H. subterraneus routinely do not catabolize stored body fat as an energy source.

Table 3. ANOVA results and regression coefficients for weight specific metabolic rates and water budget components as functions of ambient temperature $\left(T_{1}\right)$. Regression equations are of the form $y=a x^{2}+b x+c$ or $y=b x+c$ where $x=T_{a}$ in $\mathrm{C}$. Dependent variables (DV) include metabolic rate (cal/g/hr), crop water gain (CWG), metabolic water gain (MWG), total water gain (TWG), mixed wastes water loss (WWL) and evaporative water loss (EWL), all in $\mathrm{mg} / \mathrm{g} / \mathrm{hr}$. In all cases, $P<0.0001$, except ${ }^{*}$, where $P=0.0086$

\begin{tabular}{|c|c|c|c|c|c|c|}
\hline DV & $\mathrm{a}$ & $b$ & $c$ & $F$ & $\mathrm{df}$ & $r^{2}$ \\
\hline \multicolumn{7}{|c|}{$H$, subterraneus (males) } \\
\hline MR & $\begin{array}{c}0.1178 \\
(0.0167)\end{array}$ & $\begin{array}{c}-2.971 \\
(0.584)\end{array}$ & $\begin{array}{l}22.08 \\
(4.80)\end{array}$ & 121.73 & 2,21 & 0.9206 \\
\hline CWG & $\begin{array}{c}0.07596 \\
(0.01025)\end{array}$ & $\begin{array}{c}-1.784 \\
(0.359)\end{array}$ & $\begin{array}{l}13.35 \\
(2.94)\end{array}$ & 177.54 & 2,21 & 0.9206 \\
\hline MWG & $\begin{array}{c}0.01751 \\
(0.00248)\end{array}$ & $\begin{array}{c}-0.4417 \\
(0.0868)\end{array}$ & $\begin{array}{c}3.283 \\
(0.713)\end{array}$ & 121.74 & 2,21 & 0.9206 \\
\hline TWG & $\begin{array}{c}0.09346 \\
(0.01248)\end{array}$ & $\begin{array}{l}-2.225 \\
(0.437)\end{array}$ & $\begin{array}{l}16.63 \\
(3.59)\end{array}$ & 172.54 & 2,21 & 0.9426 \\
\hline WWL & NS & & & & & \\
\hline EWL & $\begin{array}{c}0.1039 \\
(0.0157)\end{array}$ & $\begin{array}{r}-2.658 \\
(0.551)\end{array}$ & $\begin{array}{l}19.65 \\
(4.53)\end{array}$ & 100.38 & 2,21 & 0.9053 \\
\hline \multicolumn{7}{|c|}{ H. subterraneus (females) } \\
\hline MR & $\begin{array}{c}0.06445 \\
(0.02514)\end{array}$ & $\begin{array}{c}-1.376 \\
(0.880)\end{array}$ & $\begin{array}{l}11.06 \\
(7.22)\end{array}$ & 28.749 & 2,21 & 0.7325 \\
\hline CWG & $\begin{array}{c}0.05154 \\
(0.02026)\end{array}$ & $\begin{array}{c}-1.010 \\
(0.709)\end{array}$ & $\begin{array}{c}8.168 \\
(5.824)\end{array}$ & 35.298 & 2,21 & 0.7707 \\
\hline MWG & $\begin{array}{c}0.01178 \\
(0.00395)\end{array}$ & $\begin{array}{r}-0.2808 \\
(0.1383)\end{array}$ & $\begin{array}{r}2.219 \\
(1.136)\end{array}$ & 27.186 & 2,21 & 0.7214 \\
\hline TWG & $\begin{array}{c}0.06124 \\
(0.02399)\end{array}$ & $\begin{array}{c}-1.217 \\
(0.8398)\end{array}$ & $\begin{array}{c}9.832 \\
(6.896)\end{array}$ & 34.398 & 2,21 & 0.766 \\
\hline WWL & - & $\begin{array}{c}0.1277 \\
(0.0247)\end{array}$ & $\begin{array}{c}-0.9917 \\
(0.4493)\end{array}$ & 26.643 & 1.22 & 0.5477 \\
\hline EWL & $\begin{array}{c}0.06005 \\
(0.02370)\end{array}$ & $\begin{array}{c}-1.303 \\
(0.830)\end{array}$ & $\begin{array}{l}10.50 \\
(6.81)\end{array}$ & 26.761 & 2,21 & 0.7182 \\
\hline \multicolumn{7}{|c|}{ C. stygitus } \\
\hline$M R$ & $\begin{array}{c}0.01448 \\
(0.00405)\end{array}$ & $\begin{array}{c}-0.3316 \\
(0.1636)\end{array}$ & $\begin{array}{c}2.388 \\
(1.477)\end{array}$ & 54.844 & 2,44 & 0.7137 \\
\hline CWG & $\begin{array}{c}0.01163 \\
(0.00442)\end{array}$ & $\begin{array}{r}-0.2533 \\
(0.1787)\end{array}$ & $\begin{array}{c}2.038 \\
(1.614)\end{array}$ & 33.185 & 2,44 & 0.6013 \\
\hline MWG & $\begin{array}{c}0.001901 \\
(0.000532)\end{array}$ & $\begin{array}{c}-0.04354 \\
(0.2147)\end{array}$ & $\begin{array}{c}0.3135 \\
(0.1939)\end{array}$ & 54.847 & 2,44 & 0.7137 \\
\hline TWG & $\begin{array}{c}0.01354 \\
(0.00491)\end{array}$ & $\begin{array}{c}-0.2970 \\
(0.1983)\end{array}$ & $\begin{array}{c}2.347 \\
(1.790)\end{array}$ & 36.012 & 2,44 & 0.6208 \\
\hline WWL & & $\begin{array}{c}0.04881 \\
(0,01777)\end{array}$ & $\begin{array}{c}-0.1937 \\
(0.3909)\end{array}$ & $7.548^{*}$ & 1,45 & 0.1437 \\
\hline EWL & $\begin{array}{r}0.001193 \\
(0.00311)\end{array}$ & $\begin{array}{c}-0.2816 \\
(0.1258)\end{array}$ & $\begin{array}{c}1.996 \\
(1.136)\end{array}$ & 58.472 & 2,44 & 0.7266 \\
\hline
\end{tabular}

NS, not significant 
Since crop water gain (CWG), metabolic water gain (MWG), and, therefore, total water gain (TWG) are calculated directly from the rate of CWW and CDW loss, as are MR, water gains as functions of size generally parallel MR. Since the crop water fraction in male $H$. subterraneus is greater than in females (Studier et al, 1986), however, WB components in both sexes are nearly identical. Weight specific water gains in cave crickets are curvilinear (Table 1), with minimal values reached in small adults (HFL $=20.0 \mathrm{~mm}$ ) at CELW of about $0.30 \mathrm{~g}$ where values for females $(\mathrm{CWG}=1.63 \mathrm{mg} / \mathrm{g} / \mathrm{hr}, \mathrm{MWG}=$ $0.398 \mathrm{mg} / \mathrm{g} / \mathrm{hr}$ and $\mathrm{TWG}=2.04 \mathrm{mg} / \mathrm{g} / \mathrm{hr}$ ) slightly exceed those of males $(C W G=1.33 \mathrm{mg} / \mathrm{g} / \mathrm{hr}$, $\mathrm{MWG}=0.354 \mathrm{mg} / \mathrm{g} / \mathrm{hr}$ and $\mathrm{TWG}=1.68 \mathrm{mg} / \mathrm{g} / \mathrm{hr}$ ). These minimal WB components only slightly exceed values of similar sized $(0.30 \mathrm{~g})$ camel crickets of both sexes (Table 1) where $\mathrm{CWG}=1.37 \mathrm{mg} / \mathrm{g} / \mathrm{hr}$, $\mathrm{MWG}=0.293 \mathrm{mg} / \mathrm{g} / \mathrm{hr}$ and $\mathrm{TWG}=1.66 \mathrm{mg} / \mathrm{g} / \mathrm{hr}$. In both larger and smaller sized cave crickets, WB components greatly exceed values for camel crickets. In camel crickets, minimal values for WB components (Table 1) are also reached at small adult size $(C E L W=0.90 \mathrm{~g})$ where $C W G=0.661 \mathrm{mg} / \mathrm{g} / \mathrm{hr}$, $\mathrm{MWG}=0.088 \mathrm{mg} / \mathrm{g} / \mathrm{hr}$ and $\mathrm{TWG}=0.749 \mathrm{mg} / \mathrm{g} / \mathrm{hr}$. The progressive decreases in weight specific WB components in both species below minimal adult size conforms to expectations based on surface area to mass relations. The increases in weight specific WB components in crickets which exceed minimal adult size present an enigma.

In ectothermic organisms such as these crickets, $\mathrm{MR}$ is expected to rise with increasing temperature, as shown in Fig. 1 and Table 2. Absolute increase in MR is much greater in cave than camel crickets. The fact that cave crickets died very quickly and, therefore, could not be tested in $T_{\mathrm{a}} \mathrm{s}$ exceeding $25^{\circ} \mathrm{C}$ indicates much greater thermal sensitivity of $H$. $s u b$ terraneus in comparison to $C$. stygius. Relative thermal sensitivities are, however, normally discussed in terms of $Q_{10}$. These $Q_{10}$ values in the range of $13^{\circ}$ (normal cave temperature) to $23^{\circ} \mathrm{C}$ are 4.75 and 3.38 for male and female cave crickets, respectively, and 4.72 for camel crickets. Based on these $Q_{10}$ values, metabolic thermal sensitivity of female $H$. subterraneus is less than that of males whose MR increases in comparable fashion with camel crickets. Values for $Q_{10}$ in excess of 3 are relatively rare and indicate extreme thermal sensitivity of the system measured. These great thermal sensitivities indicate marked adaptation to the nearly constant cave temperatures, would greatly increase metabolic demands at higher temperatures, and would preclude voluntary epigean foraging activity in $T_{\mathrm{a}} \mathrm{s}$ much in excess of cave $T_{\mathrm{a}}$, especially in cave crickets.

Equations for weight specific WB components, including evaporative water loss (EWL) and combined wastes water loss (WWL), given in Table 3, indicate direct relations to $T_{\mathrm{a}}$. At cave $T_{\mathrm{a}}$ of $13^{\circ} \mathrm{C}$, gains and losses in female cave crickets (CWG $=4.75 \mathrm{mg} / \mathrm{g} / \mathrm{hr}, \quad \mathrm{MWG}=0.559 \mathrm{mg} / \mathrm{g} / \mathrm{hr}, \quad \mathrm{TWG}=$ $5.31 \mathrm{mg} / \mathrm{g} / \mathrm{hr}$ and $E W L=3.71 \mathrm{mg} / \mathrm{g} / \mathrm{hr}$ ) exceed those of males (CWG $=3.00 \mathrm{mg} / \mathrm{g} / \mathrm{hr}, M W G=0.500 \mathrm{mg}$ / $\mathrm{g} / \mathrm{hr}, \quad \mathrm{TWG}=3.50 \mathrm{mg} / \mathrm{g} / \mathrm{hr}$ and $\mathrm{EWL}=2.66 \mathrm{mg} /$ $\mathrm{g} / \mathrm{hr}$ ) and both greatly exceed WB components of camel crickets $(C W G=0.711 \mathrm{mg} / \mathrm{g} / \mathrm{hr}$ and $\mathrm{MWG}=$
$0.0687 \mathrm{mg} / \mathrm{g} / \mathrm{hr}, \quad \mathrm{TWG}=0.77 \mathrm{mg} / \mathrm{g} / \mathrm{hr}$ and $\mathrm{EWL}=$ $0.351 \mathrm{mg} / \mathrm{g} / \mathrm{hr}$ ). Al a $T_{\mathrm{a}}$ of $23^{\circ} \mathrm{C}$, TWG in male and female cave crickets increase by factors of 4.25 and 2.86 , respectively, while TWG in camel crickets increase 3.46 times. Increasing $T_{a}$, therefore, TWG (= total water loss, TWL) increases most profoundly in male $H$. subterraneus, least in female $H$. subterraneus and an intermediate level in C. stygius. At cave $T_{\mathrm{a}}$, water turnover in female cave crickets $(0.53 \mathrm{mg} \% / \mathrm{hr})$ exceeds that of males $(0.35 \mathrm{mg} \% / \mathrm{hr})$ and both exceed water turnover in camel crickets $(0.077 \mathrm{mg} \% / \mathrm{hr})$. At a $T_{\mathrm{a}}$ of $23^{\circ} \mathrm{C}$, water turnover in female and male cave crickets is nearly identical ( 1.52 and $1.49 \mathrm{mg} \% / \mathrm{hr}$, respectively) and is much higher than in camel crickets $(0.27 \mathrm{mg} \% / \mathrm{hr})$.

Reduced MR are characteristic of many caveadapted animals; thus, it is not surprising that MRs of the studied crickets are less than for insects in general (Kayser and Heusner, 1986). Cave crickets are also extremely sensitive to temperatures above cave temperatures, and show markedly greater metabolic demands with modest increases in ambient temperature compared to camel crickets. Cave crickets exhibit more of the features expected in cavernicoles than camel crickets. Camel crickets spend extended periods of time in the Kentucky caves only as young nymphs in the Winter. From late spring to autumn, $C$. stygius roost just inside cave entrances or in forest shelters and leave the caves frequently, almost nightly, for epigean feeding. These camel crickets mate in late summer and autumn in cave entrances and, presumably, lay their eggs in the forest. Cave crickets, conversely, are found in many cave areas throughout the entire year, and copulate and lay eggs in caves. Metabolic adaptation to cave life by $\boldsymbol{H}$. subterraneus is evidenced by a somewhat lowered MR coupled to the ability to store a very large amount of food in their crops, thus providing quite long intervals between required epigean foraging activity.

Epigean foraging activity at elevated $T_{\mathrm{a}} \mathrm{s}\left(23^{\circ} \mathrm{C}\right)$ by cave crickets is probably precluded more by increase in water losses than by increase in MR. Foraging by camel crickets at similar $T_{\mathrm{a}} \mathrm{s}$ is, however, not as stressful due to the lesser increase in water demand. The greater water turnover in cave crickets than camel crickets at cave $T_{\mathrm{a}}$ may be attributed to greater EWL in the former $(76-80 \%$ of TWG) as opposed to the latter ( $45 \%$ of TWG). Furthermore, with increasing $T_{\mathrm{a}}$, EWL of cave crickets increases more profoundly than in camel crickets. In cave crickets, rapidly rising EWL with increasing $T_{\text {a }}$ indicates the presence of highly volatile cuticular surface lipids which evaporate readily at $T_{\mathrm{a}} \mathrm{s}$ slightly in excess of cave $T_{a}$. Preliminary histologic work suggests that these differences may also relate to structural differences in cuticles which allow greater water permeability in cave crickets than camel crickets.

Acknowledgements - We thank the many people who aided in the field aspects of this study. Field work was supported by grants to both of us from the Faculty Development Fund, University of Michigan-Flint. We thank the National Park Service and its personnel for allowing us access to the caves, and the Cave Research Foundation for use of its 
facilities at Mammoth Cave National Park. This research was done in support of MACA-N-103.

\section{REFERENCES}

Barr T. C. Jr (1967) Ecological studies in the Mammoth Cave system of Kentucky. I. The biota. Int. J. Speleol. 3, 147-204.

Barr T. C. Jr and Kuehne R. A. (1971) Ecological studies in the Mammoth Cave system of Kentucky. II. The ecosystem. Anm. Speleol. 26, 47-96.

Harris J. A. (1973) Structure and dynamics of a cave population of the guano mite, Uroobovella coprophila (Womersley). Aust. J. Zool. 21, 239-275.

Hubbell T. H. (1936) A monographic revision of the genus Ceuthophilus (Orthoptera, Gryllacrididae, Raphidophorinae). Vol. 2, p. 551. University of Florida Publ. Biol., Gainesville, Florida.

Hubbell T. H. and Norton R. M. (1978) The systematics and biology of the cave-crickets of the North American Tribe Hadenoccini (Orthoptera Saltatoria: Ensifera: Rhaphidophoridae; Dolichopodinae), No. 156, 124. Misc. Publ. Mus. Zool., University of Michigan.

Kane T. C. and Poulson T. L. (1976) Foraging by cave beetles: spatial and temporal heterogeneity of prey. Ecology 57, 793-800.

Kayser C. and Heusner A. (1964) Etude comparative du metabolisme energetique dans la serie animale. $J$. Physiol. Paris 56, 489-524.
Norton R. M., Kane T. C. and Poulson T. L. (1975) The ecology of predaceous troglobitic beetle, Neaphanops tellkampfii (Coleptera: Carabidae: Trechinae). Il. Adult seasonality, feeding and recruitment. Int. J. Speleol. 7 , 55-64.

Poulson T. L. (1975) Symposium of life histories of cave beetles: an introduction. Int. J. Speleol. 7, 1-5.

Richards A. M. (1971) An ecological study of the cavernicolous fauna of the Nullarbor Plain, southern Australia. J. Zool., Lond. 164, 1-60.

Studier E. H., Lavoie K. H., Wares W. D, II and Linn J. A-M. (1986) Biocnergetics of the cave cricket, Hadenoecus subterraneus. Comp. Biochem. Physiol. 84A, 431-436.

Studier E. H., Lavoie K. H., Wares W. D., II and Linn J. A-M. (1987a) Bioenergetics of the camel cricket, Ceuthophilus stygius. Comp. Biochem. Physiol. 86A, 289-293.

Studier E. H., Lavoie K. H., Wares W. D., II, and Linn J. A-M. (1987b) Water budgets of cave crickets. Hadenoecus subterraneus, and camel crickets, Ceuthophilus stygius. Comp. Biochem. Physiol. 86A, 295-300.

Studier E. H., Lavoie K. H. and Chandler C. M. (1989) Riology of cave crickets, Hadenoecus subterraneus, and camel crickets, Ceuthophilus stygius (Insecta: Orthoptera): parasitism by hairworms. Proc. Helminth. Soc. Wash. (in press). 